\title{
SOME FACTORS AFFECTING THE SELECTION OF ELECTRONIC BANKING SERVICES BY INDIVIDUAL CUSTOMERS AT COMMERCIAL BANKS
}

\author{
NGUYEN THI CAM PHU \& TRAN ANH MINH \\ Banking University, Lac Hong University, \\ Van Lang University, Vietnam
}

https://doi.org/10.37602/IJSSMR.2020.3303

\begin{abstract}
This study examines a number of factors that influence the choice of Electronic banking (Ebanking) by individual customers at commercial banks. The model is presented with 5 factors affecting the choice to use E-banking services. The study carried out descriptive statistical methods, measuring scales (Cronbach's alpha), discovery factor analysis (EFA) with a sample of 384 individual customers using E-banking services at a commercial bank. Thereby, the authors have identified the influence of each factor affecting the choice of using E-banking services of individual customers. The results of this research will be helpful for administrators to offer solutions to contribute to improving the quality of E-banking services, thereby increasing the number of customers using E-banking services as well as the operational scale.
\end{abstract}

Keywords: Electronic banking services, E-banking, individual customers, influencing factors, choices.

\subsection{INTRODUCTION}

The advent of digital technology and the internet has made the banking sector drastically change around the world. The use of a wide range of digital and network technologies has enabled banks to provide relatively low cost, high quality online services and interact with customers and stakeholders effectively (Eisingerich and Bell, 2006; Gordon et al., 2008; Dajani and Yaseen, 2016). Electronic banking service (E-banking) is a typical product in many modern technology applications of the bank, it allows bankers to provide banking services directly to all customers; bring more convenience to users as well as help customers save time and transaction costs.

Today, E-banking plays an essential role in the world of banking and finance (Al-Ajam and Khalil, 2015). E-banking services in the world are growing fast while customers of commercial banks in Vietnam continue to perform banking transactions through traditional channels. 


\section{International Journal of Social Sciences and Management Review}

In Vietnam, with a population of more than 96 million people, $84 \%$ of them are smartphone users and online purchases tend to increase. In addition, the strong growth of the credit card market also shows the trend of non-cash consumption, contributing to the development of mobile payment services.

Up to now, most commercial banks in Vietnam have opened their own websites to introduce products, services, exchange rates, tariffs and interest rates respectively of each product. At the forefront of developing E-banking services are Asia Commercial Bank (ACB), Foreign Trade Bank (VCB), followed by Techcombank, DongA Bank, and Sacombank Commercial Bank. ... and go to state-owned commercial banks like BIDV, Agribank ...

Table 1: Results of personal accounts of payment accounts

\begin{tabular}{|l|c|c|c|c|c|c|}
\hline \multicolumn{1}{|c|}{ Targets } & $\mathbf{2 0 1 4}$ & $\mathbf{2 0 1 5}$ & $\mathbf{2 0 1 6}$ & $\mathbf{2 0 1 7}$ & $\mathbf{2 0 1 8}$ & $\mathbf{2 0 1 9}$ \\
\hline $\begin{array}{l}\text { Account numbers } \\
\text { (thousand TK) }\end{array}$ & 42.116 & 46,763 & 54,450 & 60.207 & 68,698 & 69.188 \\
\hline Balance (VND billions) & 85,374 & 115.05 & 156,318 & 202.886 & 252.177 & 325,516 \\
\hline
\end{tabular}

\section{Source: State Bank of Vietnam}

The numbers of individual payment accounts have increased sharply in recent years. As of December 31st, 2019, the total number of customer accounts reached 69,188 million accounts, went up $0.71 \%$ compared to 2018 and increased by $64 \%$ compared to 2014 . This result shows that this is a good sign, exceeding the targets which set out in the project is to promote non-cash payment and is an opportunity to develop E-banking services on the basis of existing payment deposit accounts of customers.

After identifying the role and importance of customers in the development of E-banking services, many studies about the factors affecting the choice of E-banking services of customers have attracted many domestic and foreign researchers to look closer and develop other research theories. Some researchers use grounded theories such as TRA, TPB, TPR, TAM, TAM2, IDT, which provide many factors that influence the choice of E-banking services such as customers satisfactory about the convenience, perceived risks, technological innovation, ... Venkatesh's UTAUT, ATAUT2 models (2012) showed more influential factors such as social influences that could affect the choice of E-banking service. More,

Therefore, the research to find out the factors affecting E-banking service choice of individual customers in Vietnam is a job that has multiple practical implications for both customers and service providers.

\subsection{THEORETICAL MODEL AND HYPOTHESIS DEVELOPMENT}

Currently, there are many different definitions of E-banking services. E-banking in English is Electronic Banking, abbreviated as E-banking. There are many different expressions for Ebanking, in this study, it can be understood that E-banking is banking services provided through electronic means and telecommunication networks.Currently, the bank offers its 


\section{International Journal of Social Sciences and Management Review}

Volume: 03, Issue: 03 "May - June 2020"

ISSN 2582-0176

customers E-banking products and services such as Electronic cards (Cards); automatic teller machines (ATMs); Electronic payment system at the point of sale (POS), including payment of other services; Telephone banking services (Telephone Banking); Customer service centre (Call Contact or Call Center); Internet banking services (Internet Banking or Electronic banking); Home banking services (Home Banking); Banking services via a wireless telecommunications network (Mobile Banking - Wireless Banking); Electronic wallets (eWallet) and Cryptocurrencies (Digital Cash).

\subsection{Theoretical model}

Consumer behavior is a complex field of research including studies on consumer attitudes, actions and responses. The theory of consumer shopping behaviors of (Engel et al., 1978) indicates that consumer behavior is a continuous process from recognizing needs, collecting information, reviewing choices and decisions to buy, evaluate after buying. The buying decision-making process has to go through several stages from identifying needs, seeking information, measuring measurements, purchasing, and buying behavior (Phillip Kotler, 2012). Researchers (Elbeck, 2008; Howard and Sheth, 1967; Warshaw, 1980; Fishbein and Ajzen 1975) also showed that shopping intent has a great influence on the shape of customers' purchasing decisions. Intention to use it as an assertion the customer will take action to use (Ajzen \& Feish, 1980).

The rational action theory model TRA (Ajzen and Fishbein, 1975) considers two factors: consumer attitudes (Athiyaman, 2002; Miller, 2005) and subjective standards of consumers (Gefer and Straub, 2000; Miller, 2005). The rational action theory TPB (Ajzen, 1991) argues that consumer motivation or intention is the basic motivating factor for consumer behavior. This motivation is driven by three basic factors: ergonomics, subjective standards (Eagly \& Chaiken, (1993) and cognitive-behavioural control.

Risk Perception Theory TPR (Beuer, 1960) is thought that consumer behavior of information technology products is perceived as having two risk factors: Perception of risks related to products/services (PRP - Perceived) Risk with Product / Service), (2) Perception of risks involved.

Davis (1986) proposed a widely accepted model of TAM technology that provides a basis for examining the impact of external factors on internal factors such as trust, attitudes and ideas specified. The two basic elements of the model have perceived usefulness and perceived ease of use. Perception of usefulness is the degree to which a person believes that using a particular system will enhance the performance of their own work. Perceived which is easy to use is the degree to which a person believes that using a particular system without effort.

The theory of innovation (IDT) developed by Rogers (1962) explains innovation and customers benefit from that innovation and accept new products. IDT and TAM theory are two research theories in different fields but still have similarities. The factor "Relative advantage" in innovation theory is understood as "Useful perception" in the theory of technology acceptance (TAM), the factor "Complexity" in IDT theory self-concept factor "perceived ease of use" in TAM theory. The theory of TAM and IDT is similar and complementary to explain technology adoption. Some researchers (Rudi et al, 2001; Jun Wu, 


\section{International Journal of Social Sciences and Management Review}

2005; Ndubisi and Sinti, 2006; Ali Saleh and Khalil, 2013) used to explain the factors affecting the acceptance of Ebanking services. in some countries.

The theory of technology acceptance and use (UTAUT, UTAUT2) Venkatesh et al., 2012 explains user intent and behavior for technology. UTAUT model is built on the basis of developing the previous models: TRA, TPB, TAM, IDT.

\subsection{Hypothesis development and research models}

Perceived ease of use, perceived usefulness

Perception of ease of use is the perception of users who believe that services can be used without effort (Davis, 1989). Perceived usefulness is understood as an awareness of the ability to improve the efficiency and productivity of users when using it (Davis, 1989).

Many studies in different countries that apply rational action theory (TRA, TPB, TAM), UTAUT, ... have confirmed the factor of perceived ease of use, perceived usefulness as two factors. An important factor, affecting the choice to use Ebanking service. Research by Lee et al. (2001), Venkatesh (2012), Chan and Lu (2004), Pikkrainen (2004), Luarn and Lin (2005), Alsajjan and Bander (2008), Clegg (2010), Dasgupta (2011) ), Mohammad et al (2012), Njuguna (2012), Pham Long (2013), Hernandez (2014) and many other studies on different services confirm two factors of perceived ease of use, perceived usefulness positively affecting customers' choice to accept to use e-commerce services. Therefore, the authors propose the following two hypotheses:

Hypothesis 1 (H1): Perceived ease of use has a positive effect on the choice to use Ebanking services;

Hypothesis 2 (H2): Perceived usefulness has a positive effect on the choice to use Ebanking service.

\subsection{Innovation}

Innovation reflects an open attitude to change, reflecting the need to create new and exciting (Schwartz, 1992)). According to Manning et al. (1992), an innovative consumer is someone who likes new things, likes to search for new product information, and wants to have new experiences about products. Many studies show different relationships, some of which confirm a significant positive effect between innovation and consumer acceptance (Foxall and Bhate, 1991; Paswan and Hirunyawipada, 2006; Ho and $\mathrm{Wu}, 2011)$, some studies show that the influence relationship is very weak (Im et al., 2003; Chao et al., 2012). A number of recent studies have shown that innovation has a positive effect on consumer/customer acceptance (Cao Thi Thanh, 2014; Nguyen Thi Hanh, 2016).

E-banking service is a growing service in Vietnam, commercial banks are competing to provide more and more new, modern E-banking services, applying high-tech techniques to facilitate and increase many utilities for the user. Therefore, from the empirical study of the previous author, the authors put the innovation factor in the analysis from the view that customers who are using services at banks are interested in learning new technologies and 


\section{International Journal of Social Sciences and Management Review}

techniques., like to explore modern services is the factor affecting the choice and acceptance to use E-banking services. Therefore, the study proposes the following hypothesis:

Hypothesis 3 (H3): Innovation has a positive impact on the choice to use E-banking services.

\subsection{Risk awareness}

According to Lee (2001), perceiving risks in using E-banking services is the uncertainty or anxiety that consumers perceive. Concerns that people who choose to use (or users) face when they cannot foresee the consequences of using / continuing to use the service (Chan, Lu (2004)).

In fact, customers and banks now face numerous risks when conducting electronic transactions. These problems are often beyond the control of the bank and often result in money loss in the customer's account. When using E-banking, customers perform all operations instead of being served by bank staff. Therefore, there will not be any direct interaction between customers and bank staff, therefore the risk of technology used is also a risk that customers must consider before making a choice and accepting receive E-banking services of that bank. Many previous studies have identified perceived risk influences on customers' choice to use services (Lee, 2001; Brown, 2003; Laforet and Li, 2005; Chan and $\mathrm{Lu}, 2004)$ confirms that risk factors negatively affect potential customers' choice to use the service. The higher the perceived risk of security and the trust of suppliers to consumers, the lower the perceived usefulness of e-commerce (Lee, 2001). The risks of security and confidentiality through internet transactions reduce the perceived usefulness of customers (Chan and Lu, 2004). Therefore, the authors propose the following two hypotheses:

Hypothesis 4 (H4): Risk awareness impact opposite to the choice of using Ebanking service.

\subsection{Social influence}

Under the UTAUT model (Venkatesh et al., 2003) the social influence is thought to be the extent to which an individual realizes that important people recommend the new system. For mobile banking, the social impact can be concretized as the impact of the social environment around a customer who intends to choose to use mobile banking services as reference group's family, leader, friend and colleague (Phillip Kotler, 2012). In other words, the information and incentives provided by those around the customer play a role in helping customers intent on technology (Alalwan, Dwivingi, \& Williams, 2016; Alalwan, Rana et al. ., 2015).

Vietnam is a developing country, its intellectual level is not as high as advanced countries in the world and the bandwagon effect has become very popular. The influence of relatives, friends, or other entities in the society will have a great impact on the attitude or perceived risks to customers using the bank's services, thereby creating chain effects. Social influence and the positive feedbacks will reduce the fear of security risks, increase the number of new customers and create momentum for the growth of revenues, profits and market shares for enterprises. Therefore, the study proposes the following hypothesis:

Hypothesis 5 (H5): Social influence factors have a positive impact on the choice of using Ebanking services. 


\section{International Journal of Social Sciences and Management Review}

Volume: 03, Issue: 03 “May - June 2020”

ISSN 2582-0176

Based on the research overviews of multiple types of research from different countries and specified characteristics of E-banking service development in Vietnam, the author inherits previous studies to propose a research model of influential factors when choosing to use Ebanking services in the context of commercial banks in Ho Chi Minh City including the following factors: (1) Perceived ease of use, (2) Perceived Usefulness, (3) Innovation, (4) Risk identification, (5) Social influence. The dependent variable is the option to use Ebanking services.

Figure 1: Proposed research model

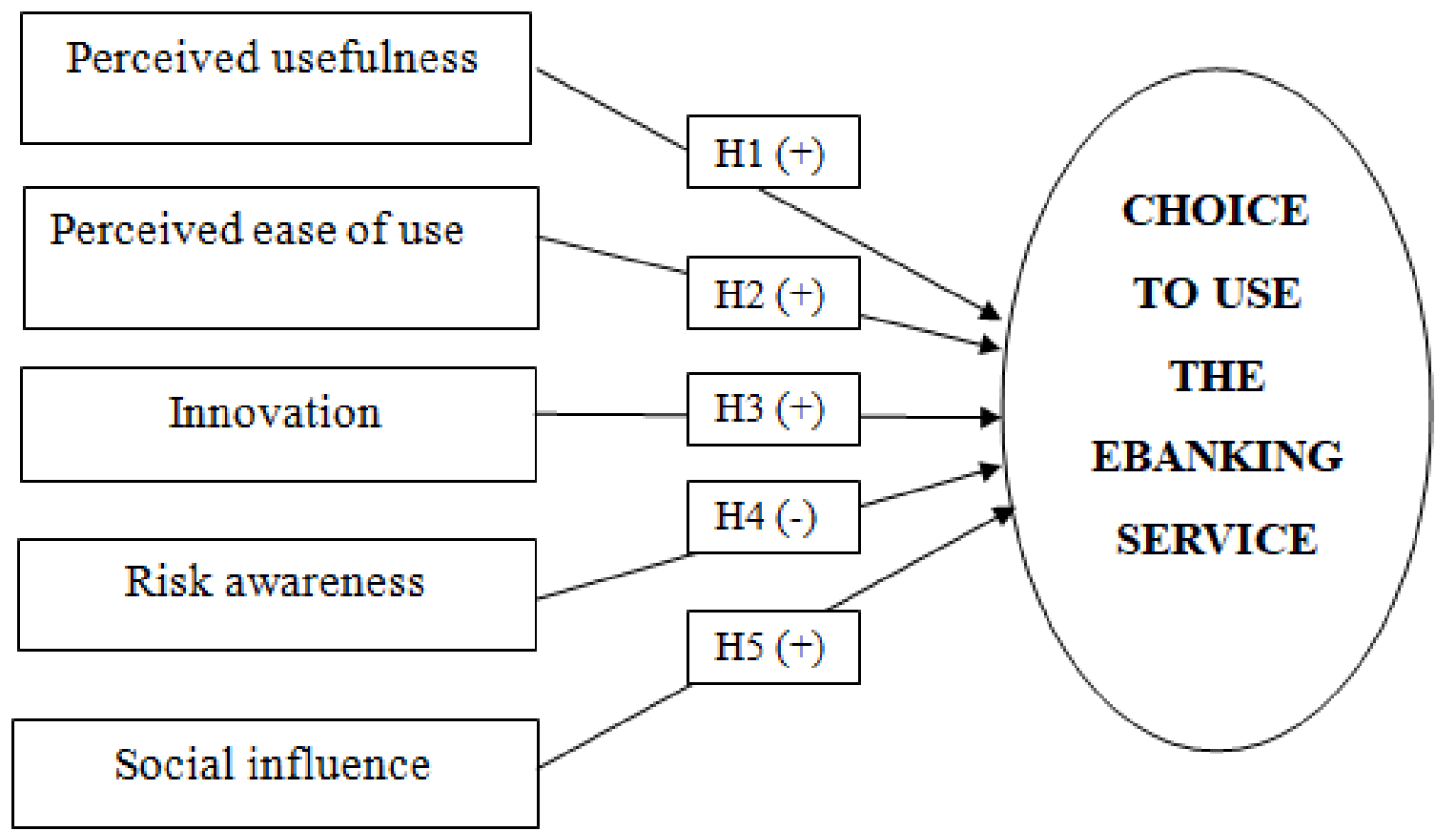

Source: Author's proposal

\subsection{RESEARCH METHODOLOGY}

The research team based on previous studies and consulted experts in banking and finance industry to complete the scale of this study, a five-component scale: Perception of Usefulness (PU), Perceived Ease of Use (PEU), Innovation (I), Risk Awareness (RR), Social Influence (SI), these components are composed of 16 observed variables and the last component is the choice to use E-banking services in Ho Chi Minh City.

Subjects, context and study time: Subjects are individuals who are using E-banking services in HCMC. Research subjects mostly come from Ho Chi Minh City. The study period is from May 2019 to February 2020

Scale design and data collection method: These stages are conducted through two main steps: qualitative research and quantitative research. Qualitative research through direct discussion 


\section{International Journal of Social Sciences and Management Review}

methods with experts in the field of banking and finance. Quantitative research was conducted through direct survey questionnaires and online survey questionnaires (Google forms). The questionnaires are based on a revised scale and are measured on a 5-point Likert scale with 1 being strongly disagreed and 5 strongly agree.

Data processing method: After collecting the questionnaire surveys, the authors conducted data entry and cleaned the data processed using SPSS 20.0 software. Data analysis will be conducted through two steps: Assessing the reliability of the scale by Cronbach's Alpha coefficients and the values by EFA discovery factor analysis. In order for the scale to be accepted, it will remove variables with item - total correlation of less than 0.3 and Cronbach's alpha coefficient less than 0.6. Further, in the EFA discovery factor analysis, variables with Factor Loading or less than 0.5 will be removed from the scale because of poor correlation with the underlying factor (the concept of measurement). The final step is to test the model by multivariate regression with $5 \%$ significance level and evaluate the importance of the factors affecting the choice of using E-banking services in Ho Chi Minh City.

Sample size: According to Hair et al., The general rule for the minimum sample size in exploratory factor analysis is 5 times the number of observed variables and the number of samples suitable for multivariate regression analysis is also 5 times the number. observed variables. This research model has 16 observed variables, so the minimum sample size will be 80 , for this study, we use primary data with 384 valid samples, so the number of samples is sufficient standard.

\subsection{RESEARCH RESULTS}

\subsection{Descriptive statistics}

Gender: Of the 400 votes issued, 384 votes were collected, accounting for $96 \%$ of the valid votes, $61.6 \%$ of which were male, $38.4 \%$ of female respondents; Age (years): Under 25 years old accounted for $26.2 \%$, from 25 to under 50 years old accounted for $49.5 \%$, from 50 years old accounted for 24.3\%; Educational Qualification: Higher school 27.4\%, college's degree, $24.5 \%$, Bachelor's degree, 21.9\%, Postgraduate degree and 26.2\% higher education; Occupation: Private sector $34.4 \%$, Government or semi-government sector for $27.4 \%$, the rest were other subjects; Monthly income: The group with income below 5 million accounted for the highest proportion of $26.4 \%$, followed by the income group above 15 million, accounting for $25.7 \%$, the income group from 5 to 10 million accounted for $25.2 \%$. $\%$, income from 10 to 15 million accounting for $22.6 \%$.

\subsection{Measurement of reliability of scales (Cronbach's Alpha)}

A well-evaluated factor when Cronbach's alpha coefficient is greater than or equal to 0.8 , Cronbach's alpha coefficient of 0.6 or higher is usable (Peterson, 1994). According to Nunnally \& Burntein (1994), variables with total correlation coefficient less than 0.3 will be excluded from the scale due to poor correlation with other variables in the same question.

Table 2: Cronbach's alpha coefficient of factor 


\section{International Journal of Social Sciences and Management Review}

Volume: 03, Issue: 03 "May - June 2020"

ISSN 2582-0176

\begin{tabular}{|ll|l|}
\hline KMO Coefficient & & 0.773 \\
\hline Bartlett Testing & DF & 465 \\
\hline & Sig & 0,000 \\
\hline
\end{tabular}

Source: Data processing results on SPSS software.

\subsection{The result of factor analysis (EFA)}

The analysis results are in table $2, \mathrm{KMO}$ coefficient $=0.773$ so factor analysis is appropriate. The Bartlett test is statistically significant $(\mathrm{Sig} \leq 0.05)$, the observed variables are correlated with each other in the whole (Hair, Anderson, Tatham and William 2006). Accordingly, the sig of the above test is 0.000 so the variables are correlated with each other in the population. The results of the KMO coefficient and Bartlett test in Table 3 above show that it is eligible for factor analysis.

Table 3. KMO Coefficient and Bartlett Test

\begin{tabular}{|l|c|}
\hline & Cronbach's Alpha coefficient \\
\hline Perceived usefulness (PU) & 0.789 \\
Perceived ease of use (PEU) & 0.728 \\
Innovative (I) & 0.605 \\
Risk Awareness & 0.637 \\
Social influence (SI) & 0.613 \\
\hline
\end{tabular}

Source: Data processing results on SPSS.

Analysis of discoverable factors extracted 5 independent factors from 16 observed variables; the elements were classified into component groups in the element rotation matrix in accordance with the theoretical model. The EFA analysis results are presented in Table 4.

The factor analysis results are presented in Table 4, 5 factors with Eigenvalues (amount of variability explained by a factor) greater than 1 were extracted from 16 observed variables and Cumulative (extracted variance) has value $62.058 \%$ tells us that these 5 factors explain $62.058 \%$ of the variability of data (Gerbing and Anderson, 1988).

Table 4: Factor rotation results

Matrixa pattern

\begin{tabular}{|lllllll|}
\hline & & & & & & \\
Observed Variables & Factor & & & & \\
& 1 & 2 & 3 & 4 & 5 \\
\hline 1 & .812 & & & & \\
\hline
\end{tabular}




\section{International Journal of Social Sciences and Management Review}

Volume: 03, Issue: 03 “May - June 2020”

ISSN 2582-0176

\begin{tabular}{|c|c|c|c|c|c|}
\hline I2 & .804 & & & & \\
\hline I3 & .775 & & & & \\
\hline I4 & .655 & & & & \\
\hline PEU1 & & .829 & & & \\
\hline PEU3 & & .737 & & & \\
\hline PEU4 & & .661 & & & \\
\hline PEU2 & & .614 & & & \\
\hline HI3 & & & .780 & & \\
\hline PU1 & & & .762 & & \\
\hline PU2 & & & .605 & & \\
\hline $\mathrm{R} 1$ & & & & .823 & \\
\hline R2 & & & & .785 & \\
\hline R3 & & & & .585 & \\
\hline SI1 & & & & & .827 \\
\hline SI2 & & & & & .811 \\
\hline Eigenvalues & 3,908 & $\begin{array}{c}1,79 \\
0\end{array}$ & 1,661 & 1,346 & 1,223 \\
\hline Cumulative (\%) & 16,324 & $\begin{array}{c}30.17 \\
\mathbf{0}\end{array}$ & 41,569 & 52,901 & 162.058 \\
\hline
\end{tabular}

Source: Data processing results on SPSS software.

\subsection{Regression analysis}

Regression analysis results show that the adjusted R2 coefficient $=88.5 \%$ means that $88.5 \%$ of the variation of factors affecting Electronic banking service selection is explained by factors. Elements are included in the model. The coefficient Sig.F $=0.00$ is much smaller than the significance level of $\alpha=5 \%$, so the regression model makes sense, i.e. the independent variables affect the dependent variable. In addition, the variance magnification (VIF) of the variables in the model is much smaller than 10 , so we can conclude that the variables included in the model do not have multi-collinear phenomena (Mai Van Nam, 2008). 


\section{International Journal of Social Sciences and Management Review}

Volume: 03, Issue: 03 "May - June 2020"

ISSN 2582-0176

The above analysis results show that all 5 variables included in the model are statistically significant (Sig. $<10 \%$ ). Based on the regression results, the five variables included in the model are positively correlated with the degree of influence on the choice of Electronic Banking services. In particular, the factor "Perceived ease of use (PEU)" coefficient $\beta=0.398$ is the most influential factor. Next is the factor "Perceived usefulness (PU) with coefficient $\beta=0.362$ is the second most powerful factor. The third factor is the factor "Innovation (I)" with the coefficient $\beta=0.257$. The fourth influential factor is the factor "Social influence (social) has the coefficient $\beta=0.175$. Factors having the opposite effect" "Risk awareness (R)" have the coefficient $\beta=-0.284$.

\subsection{CONCLUSION}

Based on the overview of theories and pre-research studies, the model and the factors affecting the choice of E-banking services have been proposed. The authors have also built a scale to study the factors on the basis of definition development and through the use of SPSS 20.0 analytical software, analytical research with a sample of 384 research units. Cronbach's Alpha, EFA results show that five factors: Perceived ease of use (PEU), Perceived usefulness (PU), Innovation (I), Social influence (SI) affect Customer's choice to use Ebanking service.

Regarding the impact of the factors on the choice of using E-banking services: Hypotheses $\mathrm{H} 1, \mathrm{H} 2, \mathrm{H} 3, \mathrm{H} 4, \mathrm{H} 5$, are approved to confirm the Perceived easy to use (PEU), Perceived usefulness (PU), Innovation (I), Social influence (SI) positively impact with the choice of using E-banking service as the factors increase, the choice to use E-banking service Customers will increase. The Risk awareness (R) factor has a negative impact on customers 'choice to use E-banking service, as this factor increases, their customers' choice to use Ebanking services will decrease.

The results of this research will be the basis for administrators to offer solutions to help improve the quality of E-banking services, thereby increasing the number of customers using Ebanking services as well as the scale of operations, diversification of products and services at the bank.

\section{REFERENCES}

Alalwan, AA, Dwivedi, Y., Rana, NP, \& Williams, MD (2016), "Consumer adoption of mobile banking in Jordan: Examining the role of usefulness, ease of use, perceived risk and self-efficacy", Journalof Enterprise Information Management, 29 (1).

Alalwan, AA, Dwivedi, YK, Rana, NP, Lal, B., \& Williams, MD (2015), "Consumer adoption of Internet banking in Jordan: Examining the role of hedonic motivation, habit, self-efficacy and trust", Journal of Financial Services Marketing, 20 (2), 145-157.

Al-Ajam Ali, S. and Khalil, MN (2015), "Challenges of adoption of internet banking services in Yemen", International Journal of Bank Marketing, Vol. 33 No. 2, pp. 178-194.

Ajzen I \& Fishbein M. (1980), Understanding Attitudes and Predicting Social Behavior, Prentice-Hal, Englewood Cliffs, New Jersey. 


\section{International Journal of Social Sciences and Management Review}

Volume: 03, Issue: 03 "May - June 2020"

ISSN 2582-0176

Ajzen I. (1991), "The Theory of Planned Behavior", Organizational Behavior \& Human Decision Processes, 50, 179-211.

Chan, S. and Lu, M. (2004), "Understanding internet banking adoption and use behavior: a Hong Kong perspective", Journal of Global Information Management, Vol. 12, 21-43.

Chao et al. (2012), "Consumer innovativeness influence on really new product adoption", Australasian Marketing Journal, 20, 211-217.

Clegg B., Abdullah S., Gholami R. (2010), Internet banking acceptance in the context of developing countries: An extension of the technology acceptance model. Aston business school, UK

Dasgupta, SP, Rik; Fuloria, S. (2011), "Factors Affecting Behavioral Intentions towards Mobile Banking Usage: Empirical Evidence from India". Romanian Journal of Marketing, (1), 6-28.

Davis FD, (1993), "User acceptance of information technology: System characteristics, user perceptions \& behavioural varied", International journal of Man-Machine, 38, 475-487.

Davis, FD (1989), "Perceived usefulness, perceived ease of use, \& user acceptance of information technology", MIS Quarterly, 319-340.

Dajani, D. and Yaseen, SG (2016), "The applicability of technology acceptance models in the Arab business setting", Journal of Business and Retail Management Research, Vol. 10 No. 3.

Eisingerich, A. and Bell, S. (2006), "Relationship marketing in the financial services industries: the importance of customer education, participation and problem management for customer loyalty", Journal of Financial Services Marketing, Vol. 10 No. 4, pp. 86-97.

Foxall and Bhate (1991), "Cognitive style, personal involvement and situation as determinants of computer use", Technovation, 11, 183-200.

Gordon, TL, Pires, GD and Stanton, J. (2008), "The relationship marketing orientation of Hong Kong financial services industry managers and its link to business performance", Journal of Financial Services Marketing, Vol. 13 No. 3, pp. 193203.

Gu, JC, Lee, SC, and Suh, YH (2009), "Determinants of behavioral intention to mobile banking", Expert Systems with Applications, Vol. 36 No. 9, 11605 11616.

Im, S., Bayus, BL and Mason, CH (2003), "An empirical study of innate consumer innovativeness, personal characteristics, and new product adoption behavior", Journal of the Academy of Marketing Science, No. 31, 61-73.

Laforet, S. and Li, Xiaoyan (2005), "Consumers' attitudes towards online and mobile banking in China", The International Journal of Bank Marketing, Vol. 23 No. 4/5, 362-380.

Luarn, P., \& Lin, HH (2005), "Toward an understanding of the behavioral intention to use mobile banking" Computers in human behavior, 21 (6), 873-891.

Martins, G., Oliveira, T., \& Popovic, A. (2014), "Understanding the Internet 


\section{International Journal of Social Sciences and Management Review}

Volume: 03, Issue: 03 "May - June 2020"

ISSN 2582-0176

bankingadoption: A unified theory of acceptance and use of technology and perceivedrisk application", International Journal of Information Management, $34(1), 1-13$.

Mohammad O. Al-Smadi (2012), "Factors dramatically Adoption of Electronic Banking: An analysis of theperspectives of banks' customers", International journal of business and social science, 3 (17) 294-309.

Mai Van Nam (2008), "Econometrics", Culture and Information Publishing House.

Njuguna, PK, Ritho, C., Olweny, T., \& Wanderi, MP (2012), "Internet banking adoption in Kenya: The case of Nairobi County", International Journal of Business and Social Science, 3 (18), 903 - 930.

Paswan and Hirunyawipada (2006), "Consumer innovativeness and perceived risk: implications for high technology product adoption", Journal of Consumer Marketing, No. 4/23, 182-198.

Pham Long, Cao Y. Nhi, Nguyen D. Thanh, Tran T. Phong (2013), "Structural models for E-Banking Adoption in Vietnam", International journal of enterprise information system, 9 (1) 31-48.

Pikkarainen, T., Pikkarainen, K., Karjaluoto, H., \& Pahnila, S. (2004), "Consumer acceptance of online banking: an extension of the technology acceptance model", Internet research, 14 (3), 224- 235.

Riquelme, HE, \& Rios, RE (2010), "The moderating effect of gender in the adoption of Mobile banking", International Journal of Bank Marketing, 28 (5), 328-341

Schwartz, SH (1992), "Universals in the content and structure of values: theoretical advancing and empirical tests in 20 countries, in Zanna, M. (Ed.)", Advances in Experimental Social Psychology, 28 (5), 1- 65.

Venkatesh, VYL Thong, J., \& Xu, X. (2012), "Consumer acceptance and use of information Technology: Extending the unified theory of acceptance and use of technology", MIS Quarterly, 36 (1), 157-178.

Yu, CS (2012), "Factors diverse individuals to adopt Mobile banking: Empirical evidence from the UTAUT model", Journal of Electronic Commerce Research, 13(2), 104-121. 